\title{
Genealogy and educational research
}

Christensen, Gerd

Published in:

International Journal of Qualitative Studies in Education

DOI:

10.1080/09518398.2016.1162871

Publication date:

2016

Document version

Peer reviewed version

Citation for published version (APA):

Christensen, G. (2016). Genealogy and educational research. International Journal of Qualitative Studies in Education, 29(6), 763-776. https://doi.org/10.1080/09518398.2016.1162871 


\section{Genealogy and educational research}

Gerd Christensen, Associate Professor, Ph.D.

Dept. of Media, Cognition and Communication,

University of Copenhagen

Denmark 
When the educated subject is analysed as a product of discoursive technologies, the workings of power at the level of subject become susceptible to critique. The critique is an attempt to affect a more nuanced view of the relations among educational practices that embody assumptions about the whole child, developmentality, and interactionism. In that way, those of us who engage in educational practices may become more aware of the ways discourses have already shaped our thinking about what it means to teach and to learn.

(Fendler, 2001, p. 121)

\section{Introduction}

Every discipline has its founding assumptions, which function as an outset for the practitioner's way of coping with practice. This is also the case in pedagogy and education. While the field of education concern the human individual, a lot of the assumptions will refer to the psychological domain i.e. assumptions about the human being, its competencies and the ways the competencies can be optimized. As Lynn Fendler points out in the quotation above, the critical analyses of the fundamental assumptions are a condition for reflection within the field of education.

The aim of this paper is to dig a little deeper into the founding assumptions of contemporary Danish education, and to unravel the complexity and intertwined-ness of these concepts. Among others, this is done in order to search for the mechanisms for subjectivation (as a student, as a teacher), which are established. Genealogy is one of the means for this kind of critique. Hence, genealogy can unravel the complicated network of assumptions that exists in contemporary educational practices. As a method, genealogy is known from the work of the French philosopher Michel Foucault, whose genealogies of punishment, sexuality and mental illness are all genealogies of the modern subject. As such, the paper also demonstrates the potentials of genealogy as a qualitative method in poststructuralist research (Christensen 2013; Meadmore et al 2010; Villadsen 2006; Fendler 2001). 
After introducing genealogy as a method, the analysis of contemporary Danish education show, that following contemporary pedagogical concepts back in time can provide important insight into their founding assumptions and the way they have and still are - gaining influence from psychology as a science. Thus, the analysis can provide insight into, on the one hand, how the subject is constituted through pedagogical discourse, and on the other hand, how intertwined quite different norms are in education. The genealogical traces, which are identified, may be specific for a Danish context, but can also be considered as particular traits of what we call 'neo-liberalism': on the one hand an increasing individualism and claim for the individuals right to freedom and autonomy; on the other hand an expanding demand for control, structure and leadership (Mik-Meyer \& Villadsen 2007: 9).

\section{Education and psychology}

As a method, genealogy rests on an ontological concept of the human subject, which repudiates the subject as a universal phenomenon in possession of an essence that represents 'true humanity'. In opposition, Foucault claimed the human subject to be a thoroughly contingent and historical entity that is constructed through the productive power of discourse (Foucault 1994). Thus, Foucault rejects the Marxist' conception of power as repression. Alternatively, he defines power as a foremost productive force, which only exist in relation to knowledge. Knowledge and power are separate but intertwined domains; a perception that led to Foucault's concept of power/knowledge complex. Power/knowledge can be considered as a force, that has the human subject as its primary product (Ibid.).

Through his genealogies, Foucault identified how individuals become subjects through the opportunities, which exist in the discoursive formations that are framed by power/knowledge. According to Foucault, the practice of subjetification is simultaneously a practice of differentiation and thus of normalization: while distinguishing between 'the 
normal human being' and 'the not-normal human being', individuals are defined within these categories (Foucault 1980).

This has a specific relevance in relation to a discipline, which, as it is the case with the field of education, implies the dimension of an institutionalized practice (Foucault 1979). While the founding assumptions are functioning as directives for activities, they will orchestrate the options for the individuals engaged in a specific practice. This means that a certain understanding of 'the good' and 'the bad', 'the appropriate' and 'the not-appropriate', creates the conditions for the subjects in a specific practice. This is what Lynn Fendler claims in the quotation above; underscoring that discourse is already limiting the opportunities beforehand of practice (Fendler 2001). As a discipline, education in Denmark is characterized as a field of knowledge, which concerns topics like upbringing, teaching, learning, development, socialization and bildung (see e.g. http://mef.ku.dk/ominstituttet/fag/paedagogik/). These topics are all concerning the relation between the individual and its context. In order to comprehend this variation of topics, the field of education is among others applying psychology as a kind of 'helping discipline'. This mean, that the knowledge of psychology among others contributes with theories that makes it possible to comprehend the individual's mental conditions such as feelings, thinking, cognition, memory, perception, learning and development (see e.g. $\underline{\text { Ibid.)}}$.

This is not far from one of the roles of psychology that Fendler identifies: as policy/management: '[...] psychology discourses makes the messy world of teaching and organize the unruly practices to make them appear rational and manageable' (Fendler 2012). While Fendler's analysis is focused on teacher's education, profession and professionalization, this paper treats the discipline of 'education' in a broader sense: as the establishment of ideas on the field of pedagogy from preschool to adult education. And though there are similarities, the field of education in Denmark has its own quirks that will be outlined and analysed in this paper. 


\section{Education and psychology in Denmark}

In Denmark, the position of psychology in the field of education is not necessarily dependant on evidence based knowledge and quantitative studies of effect. A great deal of the Danish research within psychology, as well as in educational studies, is qualitative. Thus, the role of psychology in education and pedagogy in Denmark is foremost conceptual, theoretical and analytical. Never the less, through its status as a science, psychology has a certain position, which Foucault would define as a power/knowledge complex. This is consistent with Fendler's indication: 'I understand developmental psychology as a discourse that constructs human growth and change in scientific terms' (Fendler 2001).

The status of psychology as a power/knowledge complex in education and pedagogy points at another important difference between education and psychology: the question of normativity. While psychology claims the role as a science and thus to be searching insight into the human mind and its motives for actions (Nielsen, 2005, p. 70), education and pedagogy is more explicitly normative, hence ' $[\ldots]$ aiming the development of the persons consciousness and actions in certain directions which is considered as good and important or necessary' (Ibid; own translation and italics). Or, as the Danish educational researcher Nepper Larsen says: pedagogy is always aiming at a goal for the individuals concerned (Larsen 2014). In psychology, the normativity is silenced and seemingly replaced by science. As such, psychology infiltrates pedagogy and the field of education (Fendler 2001; Walkerdine 1998).

According to Tamboukou '[...] Foucault's genealogies pose the question of which kinds of practices tied to which kinds of external conditions determine the different knowledge in which we our selves figure' (Tamboukou 1999, p. 202). Thus, the knowledge-practice (psychology-pedagogic) relation in education presumably makes the field particularly relevant for a genealogical analysis. 


\section{Genealogy as a method}

Genealogy was Foucault's term for a method, which was aiming at comprehending the ways in which conditions for subjectification are changing over time. In his approach, Foucault was inspired by Friedrich Nietzsche's genealogy Zur Genealogie der Moral (Foucault, 1984; Nietzsche, 1993. In this publication, Nietzsche followed the origin of the Christian morality through a reversion of the moral values in early Greek ethics. To Nietzsche, this was a story of the degeneration of the Western culture and the human beings.

As a method, genealogy is based on an excavation of historical texts. But in contrast to academic historical research, the matter of concern in genealogy is not the past, but the present (Meadmore et al 2010; Villadsen 2006; Tamboukou 1999). Thus, genealogy whites the history of the becoming of the contemporary subject. And even though Nietzsche named genealogy 'the true history' (das wirklische Historie), genealogy differs from a historical research through a lack of chronology and through its reverse research process.

Thus, a genealogy takes its outset in the contemporary phenomena and tries to investigate its genesis as descent (Herkunft in opposition to Ursprung). As Foucault points out, a genealogy identifies the discursive sediments, ruptures and transformations, which have been an integral part of the descent of the phenomena: '[...] it is to identify the accidents, the minute deviations - or conversely, the complete reversals - the errors, the false appraisals, and the faulty calculations that gave birth to those things that continue to exist and have value for us [...]' (Foucault 1984, p. 79).

Foucault is pointing at three essential conditions for the genealogy: 1) that the genealogical approach implies a repudiation of the phenomenon as essence; 2) that the powers, that are responsible for the origin of the phenomenon is not considered as founded in specific persons or conditions; and 3) that searching for the truth of the origin of a phenomenon is never the goal of a genealogy. To the contrary, a genealogy is an 
attempt to outline a possible account for the origin of a phenomenon: to write one of the in principle - multitude of narratives of its decent (ibid, p. 63).

Thus, doing genealogy implies a critical approach; not just accepting practices as they are, or consider them a result of a 'natural development' that is always leading to improvement and enhancement of the society and the life of human beings. Critique is imbedded in an insight into the historicity of the phenomena as well as into the discursive relations of power, which are attached to the process (Geuss, 2002; Meadmore et al 2010).

When genealogy is applied into educational research it offers the opportunity to gain insight into contemporary pedagogical assumptions and, thus, to consider them in a different perspective. This implies a derivative of the struggles, which has taken place during their genesis. Thus, the method offers the opportunity for analyzing the remnants of former understandings in the contemporary discursive formation; anticipations, which are forgotten, displaced or silenced, but that never the less are function as a powerful constitutive for the construction of the subject of the practice of education.

\section{Genealogy applied}

According Foucault, a genealogy consists in an examination of a large amount of texts concerning the topic. The outset is taken in texts, which are frequently quoted: 'Genealogy is grey, meticulous, and patiently documentary. It operates on a field of entangled and confused parchments, on documents that have been scratched over and recopied many times' (Foucault, 1984, p. 76). The analysis is not focused on the distinction between descriptive and prescriptive texts, hence both are considered intertwined as discursive elements. This means that all texts must be analyzed for the same three elements: power, knowledge and norms:

Three domains of genealogy are possible. First, a historical ontology of ourselves in relation to truth through which we constitute ourselves as subjects of knowledge; second, a historical ontology of ourselves in relation to a field of power through which we constitute ourselves as 
subjects acting on others; third, a historical ontology in relation to ethics trough which we constitute ourselves as moral agents.

(Foucault, 1984, p. 351; own italics)

While knowledge is a question of the relation between true and false and power concerns the relation between inclusion and exclusion, the norms distinguish between 'good' and 'bad'.

Albeit genealogy here is mentioned 'a method', several authors emphasize that there is no recipe for doing genealogy. Tamboukou expresses it like 'Foucault's genealogies do not offer methodological 'certainties"' (Tamboukou 1999, p. 215), while Meadmore et al claims that there is 'no blueprint for genealogy use' (Meadmore et al 2010, p. 464). Genealogy is foremost ' [...] a strong gasp at the epistemological and theoretical tension involved in asking how our educational practices function as they do' (ibid.). Thus, the genealogical analysis in this paper must be considered as one way to apply the method in accordance to the principles above. The analysis is carried out as part of a lager project concerning educational concepts in contemporary Danish education (Christensen 2008).

The outset for the genealogy was the aim to understand how we have come to conceptualize 'the child' the way we do in contemporary Danish education: on the one hand considering the student as an active, individual human being, in possession of a free will and an individual intelligence profile and on the other hand demanding increasingly more detailed documentation on the student's learning process? And how is pedagogy and psychology intertwined in this discourse - e.g. how does psychology function as a power/knowledge complex in education? As such, the genealogy in the book was inspired by the genealogies of Valerie Walkerdine (1998) and Lynn Fendler (2001).

In the present case, the material for the genealogy was an extract of texts, concerning education in Denmark. The outset was taken in current trends, which were analyzed for norms (anticipations, expectations to the subject, rules for behaviour), 
knowledge (application of scientific arguments) and power (subjectifiation, practice). In order to identify the discursive sediments, ruptures and transformations, the 'traits' were traced back to the beginning of the $20^{\text {th }}$ century. The trends are not evaluated according to whether they are 'good' or 'bad', but only in relation to which possibilities for subjectification, they constitute.

During the analyses, I was able to identify two major tendencies in Danish education during this period: individualization and structuralizing. The current emphasis on individualization can be identified in practices such as differentiated teaching methods $s^{i}$ in the focus on the student's responsibility for his own learning process, in the introduction of the student's personal logbook and in an ideal of the student's right to autonomy and control in the project studies (for the analyses, see Christensen 2008). The emphasis on structuralizing was identified in the increased demand for the teacher's control of the disruptive students in the classroom, in an increased focus on progression in the student's academic skills, in a demand of classroom management and a legal requirement of national and international scholastic aptitude test, and in a governmental demand of studying-, learning- and institutional plans in daycare and in primary school (Ibid.). 


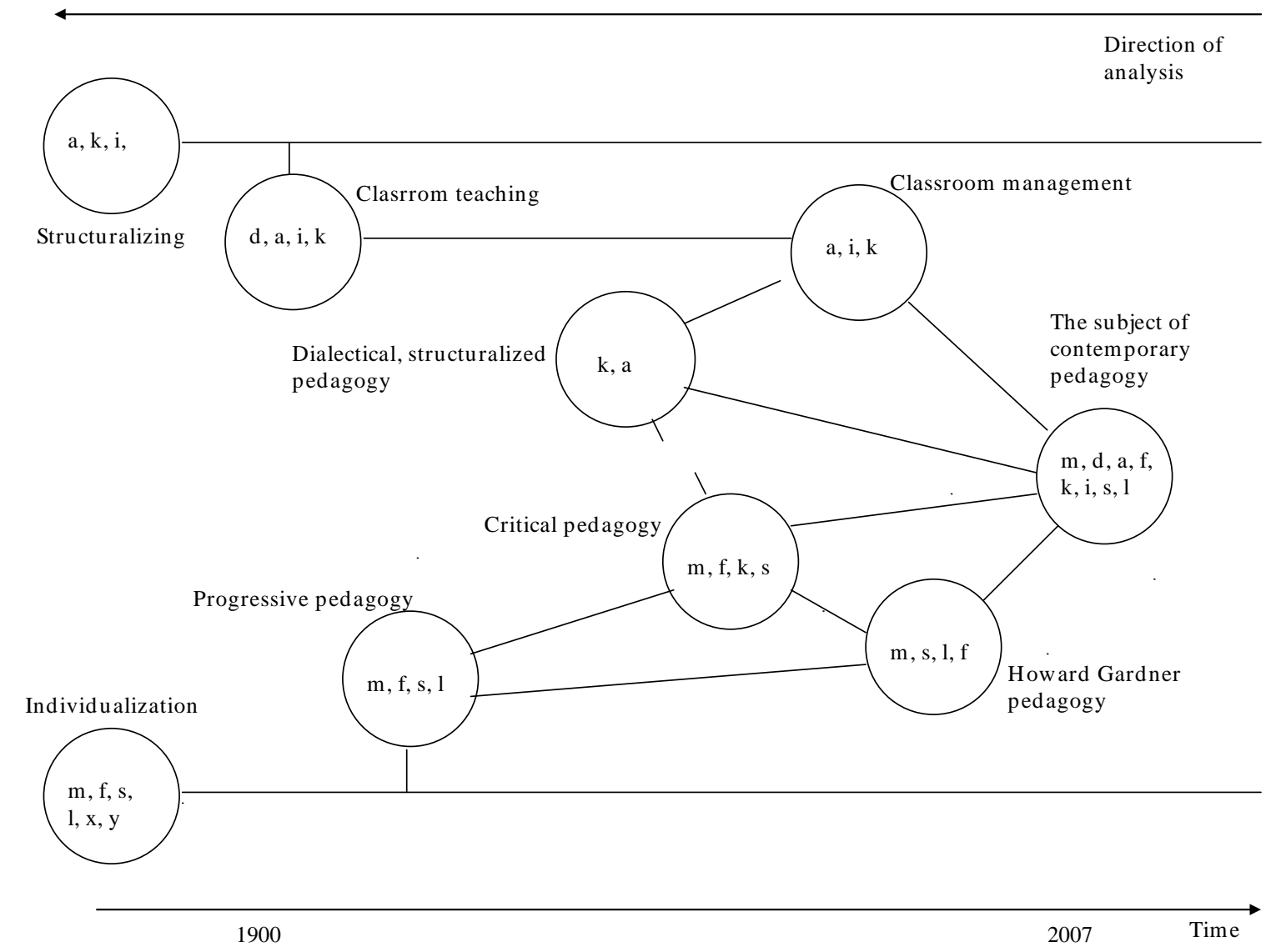

Fig. 1)

The figure is an attempt to illustrate the genealogical process in the analysis. The circles represent 'historical elements', in this case, theories on education. The lines indicate genealogical relations, while the letters represent 'historical fragments', which refer to specific perceptions or norms for the child. Kinship between educational theories and traditions presupposes that at least one fragment (letter) reiterate. The dotted lines illustrates that the analysis identify a tendency towards kinship between two educational theories, but that this is either broken or never entirely established. The arrows illustrate how the analysis is performed in an inverse chronological order and that the analysis takes its outset in the contemporary phenomenon in order to follow its genesis.

Hence, the figure not only outlines the two major tendencies or 'traces' in contemporary Danish education. It is also intending to illustrate, how I found that 
individualization and structuralizing are interlaced in the discourse. The following is an example of how this can actually be traced. The example is only covering a small piece of the analysis and, thus, a small section of the figure. Nonetheless, the figure may give an impression of the genealogical roots of the contemporary educational practices, which will be presented in the following.

Individualization: Multiple intelligences, individual learning styles and the student's responsibility for his own learning

The American psychologist Howard Gardner's theory of multiple intelligences (the MItheory) is one of the conceptions, which have dominated the Danish primary and secondary school and daycare over the last couple of decades. As the core of the theory of multiple intelligences, Howard Gardner defines 7-9 intelligences: linguistic intelligence, mathematic-logical intelligence, musical intelligence, bodily intelligence, spatial intelligence, interpersonal intelligence and intrapersonal intelligence. The last 2 intelligences, the natural and the spiritual or existential intelligence, are still under development and are therefore not included in the following discussion (Gardner, 1993; Gardner, 1996; Gardner, 1999).

The increasing popularity of the MI-theory in Denmark is identified in an explorative study of the public schools and childcare in the Danish municipalities in 2005 (Ringsmose \& Knudsen, 2005). The research showed that over $50 \%$ of the municipalities officially declared their educational policy to be directly inspired of the MI-theory. This tendency has only increased since 2005 and Gardner's conceptions are widely spread within the Danish educational system from preschool to secondary school. The MI-theory is even recommended at the homepage of the Danish Ministry of Children, Education and Equality (http://www.emu.dk/modul/de-mange-intelligenser\#).

One of the municipalities where Gardner's theory has had the most impact is in Gentofte north of Copenhagen. Thus, the principles have been a source of inspiration 
for the planning of a comprehensive project of school development in this area. The project named $S K U B$ led to renovation of both school buildings and of the educational principles of the municipality from 1998 to 2008. On the homepage the principles are explained like this:

Everyone has his own individual way of learning and individual preferences of how knowledge is most effectively adapted and internalized. The school development in Gentofte Municipality takes this variation in the children's learning into consideration and is aiming at supporting every child's special way of learning through the architecture, the pedagogy and the organization of the schools. Throughout the project has gathered inspiration from many sources, among others Dunn \& Dunn, Howard Gardner and the brain research. (http://www.skub.dk/omskub/paedagogisk inspiration.html; 24.11.2014; own translation)

The popularity of Gardner's MI theory in Denmark may be found in the circumstance that the theory is in accordance with the governmental requirement of differentiation in teaching according to the student's interests and skills (Bøgebjerg, 2006; http://www.emu.dk/modul/de-mange-intelligenser\#).

Gardner's approach was intended as an adjustment of the traditional and narrow concept of intelligence (Gardner 1999). Alternatively, Gardner suggests that intelligence comes in different forms, which means that there can be many ways of being intelligent and that every person has his own individual combination of competencies. Thus, one of Gardner's intentions was to avoid the narrow categorizing of 'the intelligent person' and 'the unintelligent person' which he considered as the consequence of the traditional de-contextualized concept of intelligence (Gardner 1999).

In place of the concept of intelligence as an inherited intellectual factor (the $g$ factor), Gardner points out that intelligence must be considered as a capacity, which can only be understood in relation to the cultural context: 'a bio-psychological potential to process information that can be activated in a cultural setting to solve problems or create products that are of value in a culture' (Gardner, 1999, p. 34). Regardless of this, Gardner maintains the term 
'intelligence' instead of the term 'competencies'. Hereby, it can be claimed, that the MItheory is gaining legitimacy from cognitive science as a paradigm of knowledge.

Cognitive science implies a focus on the individual's conceptualization due to cognitive structures, which develop over time, and which control the individual's rationality. As soon as the MI-theory functions as a source of inspiration for didactical planning, this conception of the person has specific implications for practice. On the one hand it is affecting the subjectification of the agents in the practice. On the other hand it contain specific norms, which determine the relation between inclusion and exclusion of the individuals in the practice.

\section{MI in education}

This can further be found if we dig a little deeper into the practice of the educational setting, which is inspired by the MI concept. How this can be done is sketched in the book Multiple Intelligences in the Classroom, written by Gardner's college Thomas Armstrong. In this publication, Armstrong gives specific directions for lesson planning based on the MItheory (Armstrong, 1994). An example of this is 'the function of punctuation marks' in $4^{\text {th }}$ grade (ibid, p. 61). Among the learning activities, which are described in relation to the linguistic intelligence, are 'listen to verbal explanation of punctual marks, read sentences having examples of each mark, and complete a worksheet requiring them to fill in their own marks' (ibid.). These are all activities, which may seem recognizable for teachers in relation to this topic.

Though, according to Armstrong, these activities only involve some of the intelligences and it is equally important to consider how the other intelligences can be activated in relation to this specific theme. The argument is that children learn differently and by utilizing different intelligences. In order to activate the mathematical intelligence in relation to the topic above, Armstrong recommends 'categorizing sentences' according to missing punctuation marks. To activate the spatial intelligence, Armstrong recommends that the teacher invites the students to find graphic images that correspond to the 
punctuation marks: 'question mark = a hook $[\ldots]$ a comma $=$ a brake pedal' etc. While letting the 'students make up different sounds for the punctuation marks' will activate the musical intelligence, the students will activate the bodily intelligence when they 'use their bodies to form the shapes of the different punctuation marks'. The interpersonal intelligence is recommended activated by letting groups of students compete to decide, which one is the most skilled in applying missing punctuation marks in sentences. Finally, the intrapersonal intelligence is expected to be activated as 'students are asked to create their own sentences using each of the punctuation marks; the sentences must relate to their personal lives' (ibid.).

A simple search on the Internet shows that this interpretation is frequently applied to primary school education in Denmark and is recommended by the Danish Government. The comprehension is, however, based on a conceptualization of teaching planning, which regards the relation between cognition and teaching as a one-to-one relationship. In this view, every activity, which implies numbers, is considered to affect specific identifiable structures (or even neurones) specially designed to adapt this kind of input into the human brain. As such, Armstrong legitimizes the lesson planning by reference to the human cognition, i.e. a psychological phenomenon. This is a representative of linear or causal thinking in education ${ }^{1}$.

At first sight Armstrong's interpretation and linear thinking does not seem consistent with Gardner's recommendations. Hence, Gardner maintains the claim that there is no immediate transferability between cognition and pedagogy: 'MI theory is in no way an educational prescription. There is always a gulf between scientific claims about how the mind works and the actual classroom practices' (Gardner, 1999, p. 89). Regardless of this, Gardner recommends Armstrong's work in the foreword of Multiple Intelligences in the Classroom, and hereby legitimizing his interpretation.

\footnotetext{
${ }^{1}$ I would like to thank an anonymous reviewer for this formulation - as well as for careful reading and other valuable comments to a previous version of this paper.
} 


\section{MI and the student's individual learning styles}

As apparent in the quotation from the homepage of the SKUB-project, Gardner's MItheory is frequently combined with Kenn \& Rita Dunn's theory of individual learning styles. This theory argue, that human beings gain optimal learning under different conditions and that being seated at a desks 8 hours a day is in fact suitable learning conditions for very few students (Dunn, 2003; Dunn \& Griggs, 2004; Schmidt et. al., 2003). As in the case of Gardner's intelligences, Dunn \& Dunn argue that there exists a multiplicity of learning styles and that these are a result of an individual combination of preferences.

This approach can be considered as an appeal to rethink the traditional architecture and arrangement of the classroom. Thus, applied to practice, this not only affects the pedagogy, but also the interior arrangement of the school and of the classroom. A school arranged in accordance with the principles of Gardner and Dunn \& Dunn, implies an arrangement, which makes it possible for the children to experiment and to utilize their individual intelligence- and learning profiles. This implies a flexibility and diversity of the interior: contrary to the traditional arranged classroom with tables and chairs in rows, tables and chairs must be movable in the MI-learning style classroom. In this classroom, some areas must be arranged for group work, while others are arranged so that the students can lie down or sit on the floor, while they are studying. In most Danish schools, the principles has also meant inclusion of the school corridors as part of the space for teaching and studying:

Physical environments are designed following new pedagogical principles. SKUB promoted new ways of understanding relations between teaching and learning methods and physical environments within schools. The main focus was on pupils' individual needs and on the importance of a school's physical environment for achieving excellence in learning outcomes. For example, traditional classrooms were abandoned and, instead, emphasis was put on open-learning environments. In order to use the new facilities teachers needed to implement new methods based on tailored-made approaches and pupils' needs. 
http://create2009.europa.eu/fileadmin/Content/Downloads/PDF/Projects/National projects/D K SKUB The school of the future.pdf; 27.09.2011).

This merging of Gardner's concept in Armstrong's interpretation and Dunn \& Dunn's multiplicity of learning styles is an example of individualization of the education. On the one hand it emphasizes, that the teacher is obliged to plan each lesson so that several intelligences will be activated in the individual students. On the other hand, the principles force the teacher to accept each student's individual preferences i.e. whether to lie on the floor or hang in the windowsill. In addition, the mantra of 'the student's responsibility for his own learning' (Bjørgen, 1994) is a powerful ingredient in the advancing tendency of individualization in Danish contemporary education.

\section{The progressive roots}

In its focus on the individualization of the students, this approach can be considered as a continuation of the tradition of progressivism, which in Denmark can be traced back to John Dewey and the early progressive pedagogy from the Early 1900. In Denmark, the introduction of the progressive pedagogy meant that teachers and pedagogues for the first time in history came to consider the students as individuals with personal differences and different personalities (Nørgaard, 1977). Hence, the goal of education was to 'nourish' the students' individual and 'natural' development and the educational setting should be able to contain students of all kinds i.e. 'inclusive education' (Ibid; Darling \& Nordenbo, 2003). Albeit, the MI-learning style concept is focusing on individual differences, the aim is inclusion of different 'intelligence profiles' and 'learning styles'.

However, when children are categorized or are forced to categorize themselves according to whether they are 'word-competent', 'number-competent' or 'bodily-competent' - as it recently is the case at the majority of Danish schools - they are encouraged to a certain form of self reflection that includes differentiation. This evidentially has an impact on their self-conceptualization, and can, in a Foucauldian 
perspective, be claimed to have an impact on their subjetification: they are subjectified as word-competent, number-competent or bodily competent.

Gardner's theory has as its perquisite that the child has certain competences. Thus, with Gardner's approach the child is constructed as being competent (Juul, 1999; Fendler, 2001). Furthermore, Gardner's theory of 'multiple ways of being smart' is not discussing whether 'the competencies' are evaluated differently, and whether there are competencies that are more valued in a contemporary Western society than others. Hence, also schools, which according to their own statement are inspired of Gardner's MI-theory, in practice still emphasize linguistic and mathematical education. This may be considered as a manifestation of the school's validation of these skills as more important than artistic competencies. And albeit, that the competencies are called 'intelligences' there still seem to be intelligences that are higher valuated in a Western culture like Denmark.

\section{Structuralizing: The goal-oriented planning of children's learning}

Parallel to the aim of individualization it is, however, possible to identify a different tendency in the Danish discourse of education: an increased focus on ways of structuring the educational setting and the activities of the students. This can be found in a growing concern for the student's academic skills and whether the educational setting is appropriately structured to improve these.

The concern about structure is among other initiatives manifest in a legal requirement for national scholastic aptitude test, studying plans, learning plans and institutional plans in primary schools and in daycare. These are all initiatives, which occupy an increasing amount of the teacher's time and appointment. A specific example is found in Lov om pædagogiske læreplaner i dagtilbud til born [The law on pedagogical learning plans in daycare] which was effectuated in 2004 as a section under Lov om social service [The law concerning social services.] (Socialministeriet, 2004). The text state that: 'Every daycare centre is obliged to prepare a pedagogical learning plan for the children from age 6 
months to 2 years and from age 3 years until school age that must provide opportunities for playing, learning and development' (Ibid, § 8a; my translation).

The obligations are further elaborated upon in Bekendtgørelse om temaer og mål $i$ pædagogiske læreplaner [Departmental order concerning themes and goals in pedagogical learning plans]:

The daycare institution must support the children's learning [...]. The pedagogical staff must support, manage and challenge the children's learning of which the children are the co-creators. Learning can occur during spontaneous experiences and by playing and by the staff creating or supporting situations which gives the children an opportunity for innovation, absorption, change and stimulation. (Socialministeriet, 2003.; own translation and italics)

These activities are supposed to encourage the following: 1) a balanced development of the child's personality; 2) social skills; 3) language skills; 4) bodily movements and exercise; 5) knowledge about the nature and natural phenomena; 6) knowledge about cultural modes of expression and values. In order to make sure that this is effectuated, the teacher must make follow-up and documentation on the child's learning process (Ibid.).

\section{Dialectical, structuralized pedagogy}

The aims of the Departmental order are practically equivalent with the objectives of dialectical, structuralized pedagogy, i.e. Marxist pedagogy, as presented by Stig Broström in the early 1970es and 80es:

To fulfil the objectives of the rearing of the child their forms of organization have to be structured in such a way that the areas of development are balanced. This is secured through structured plans for days, months, and years. Through the structuring of the forms of organisation it must be secured that there is a correct weighting of the areas of activity: Language skills; physical exercise; knowledge of the society and the nature; knowledge of quantities; drawing, painting and building skills and singing, music and drama activities. (Broström, 1982, p. 200; own translation) 
Currently, Broström, who is now an associate professor at the Danish University School of Education, is well known in Denmark as a dedicated proponent for learning plans in daycare.

Dialectical, structuralized pedagogy was introduced in Denmark by communist' and Marxist enclaves in the beginning of the 1970s. The theory was founded on a critique of the existing society, which was formulated as a critique of capitalism and of the upbringing of the children in the capitalist society (Diderichsen, 1976). This critique was not only aimed at the child-centred progressive pedagogy and it's promotion of individualization, but also at the critical pedagogy, which had its outset in the Frankfurt Schooli $^{\text {ii }}$ Not even critical pedagogy was considered suitable for taking care of the totality of the child's personal development in a proper (Marxist') society (Broström, 1982).

Generally, the progressive pedagogy was criticized for establishing "pseudocollectives' where features as tolerance, consideration and understanding toward others and even for the unacceptable and unadjusted - has greater value than solidarity, collectivism and class awareness' (Diderichsen, 1976, p. 35; own translation). Thus, the critique of the progressive pedagogy was not least a critique of the de-ideologisation - or the missing ideologisation - of the pedagogy. As an alternative, dialectical structuralized pedagogy pointed at collectivism and more control of the educational setting (Broström, 1982, p. 200).

The field of interest for dialectical structuralized pedagogy was pre-school education i.e. education of children ages 3 to 6 years. Of specific relevance to this group, the principles for organization are 'play, work, occupation, free activities (i.e. activities, which are not decided upon or directed by the educationalist), project-work, body care, meals, naps, walks, excursions, parties, traditions, feasts and children meeting' (Broström, 1982, p. 200; own translation). Even though the aim was control of the pedagogical setting, Broström underscored that there was no intention to reintroduce the traditional teachercentered learning: 'The existence of a structure does not mean that the children are 
reduced to objects which are left to be manipulated by the educationalist. They must be able to co-work and creatively change the structures and thereby experience that it is possible to change the world' (Ibid; own translation). The quotation is an example of how this pedagogy emphasized a dialectical relation between the child and its surroundings.

\section{The psychological inherence: Vygotsky}

The conception of development and learning in dialectical, structuralized pedagogy are founded in the work of the Russian developmental psychologist Lev Vygotsky, who was the founder of cultural-historical theory and what was later named the activity theory. Activity theory emphasizes, that the human individual develops and learns in social contexts, and that both learning and development are a social and dialectical saturated process: 'The essence of the development of the child is not a gradual socialization imposed upon the child from outside but on the contrary a gradual individualization based on the fundamental social nature of the child' (Vygotsky, 1971, p. 367; own translation).

In order to support the argument of the essentially social nature of the child, Vygotsky accentuates that: 'all advanced psychological functions in the development of the child appear on the scene twice. Firstly, as a collective and social activity, i.e. as an inter-psychological function, and secondly as an individual activity in the form of the child's inner means for thinking, i.e. an intra-psychological function' (Vygotsky in Lindquist (edt.), 2004, p. 280; own translation).

One of the central concepts in Vygotsky's theory of learning and development is The Zone of Proximal Learning. This concept emphasizes that a potential area of development exists between the present stage of development and the closest subsequent stage. Thus, The Zone of Proximal Learning is the individually defined area for learning and development, an area, which can be found for every individual in relation to any activity. 
The individual can enter into the zone with the assistance of a more competent other, which can be either an adult or a more skilled peer.

This does not mean that development implies that the child leaves a (biologically defined) stage to enter a new and more advanced one. The former stage remains in the individual, but is incorporated in the new one trough a qualitative transformation caused by a 'dialectical negation'. A dialectical negation is the result of the struggles between the contrasts in the individual, in the society and in between the individual and the society (Broström, 1982).

\section{Goal-orientation}

Thus, dialectical structuralized pedagogy emphasized that the educator works goaloriented in order to establish a frame for developing the child's psychological processes, its formation of a socialist worldview and the development of a collective consciousness (Ibid.). According to the theory, this will happen when the child participates in permanent groups or collective entities governed by fundamental organs, structures and traditions. The recommendation for group work is, thus, motivated by the claim that it contributes to the formation of the socialist citizen. ${ }^{\text {iii }}$ Through group work, the child learns to consider him self a part of a larger social structure. Thereby he develops an understanding of the term 'group discipline' which can be maintained through 'constructive and 'friendly' critique' (Broström, 1974, p. 182-183).

As it appears, the educator is in charge of selecting the contents for the education, in establishing suitable frames for learning and teaching and in organizing activities, which can encourage the activity of the children and provoke its proximal zones for development (Broström, 1982). Thus, a Marxist upbringing implies that the educators are Marxist trained and that the child's parents want a 'proletarian upbringing of their children' (Broström, 1974, p. 167; own translation). 
Assumptions like these all have a fundamental impact on the possibilities for the child's subjetification in the educational setting. By referring to learning as the vehicle for development it is legitimized to pace the developmental processes of the child. This can be done by continually learning in the periphery of the child's competencies. According to structuralized pedagogy, even playing - which is usually considered as a place of retreat for the child - must be considered an area of development and, thus, an area, which has to be governed by the educator (Ibid.).

This observation is far from the ideals of the child-centred tradition of the Danish pre-school, which has a long tradition of taking an outset in the child, its desires and inherent competencies (Ellegaard \& Stanek (eds.), 2004; Plum 2011). The debate about learning planes in daycare constructs free play and learning as oppositional activities. Prior of being a subject himself, the child in dialectical, structuralized pedagogy is considered an object for the educator and a property of the society (Christensen, 2008).

As mentioned, the developmental psychology of Vygotsky is legitimizing that the education targets its activities towards the learning and development of the child. Even playing has a central role, play must be considered as an element of learning (Vygotsky, 1971; Lindquist, 2004). The child must continually enter his zone of proximal development. Otherwise, the process of development cannot be considered optimal. These considerations can, as well as the emphasis on the importance of a more skilled 'other', equally be identified in Bekendtgørelse om temaer og mål i pædagogiske læreplaner [Departmental Order Regarding Themes and Aims in Pedagogical Learning Plans] (Socialministeriet, 2003).

\section{Transitions and relations in practice: Learning plans in Gardner's terminology} While the heavy Marxist' ideology is officially excluded from the discourse of learning plans in Danish daycare, the learning plans, which are actually executed in the institutions, can be considered as genealogically related to dialectical, structuralized 
pedagogy. One of the consequences of the increased focus on goal-orientation in preschool is a fading interest in the child's personal development (Ellegaard \& Stanek (eds.), 2004; Plum, 2011). As such, the legislation mentioned above can, on the one hand, be considered as an implicit disavowal from the Danish tradition of 'free' child-centred preschool pedagogy (Ibid.). This is recognized of Stig Broström: 'This is a demand for the child care institutions to change focus from the developmental and psychological interest to the inclusion of a didactical view of the child while creating a didactical profile' (Broström, 2004, p. 41; own translation).

On the other hand, it is interesting that the implementation of the learning planes in the daycare institutions seems to involve the application of Gardner's MI-theory. The domains for development, which are defined in the law, emphasize the development of the child's personality, social skills, language, physical exercise, and knowledge about the nature, culture and values. All these areas are interpreted with reference to Gardner's concept of intelligence. Many examples of this practice can be found on the internet (see e.g. http://www.solbakkens.dk/laereplanerfor20142015.asp;

http://kaskelotten.esbjergkommune.dk/paedagogik/laereplan-for-daginstitutioner.aspx; http://dalensbh.viborg.dk/FrontEnd.aspx?id=887929).

It is apparent, that the rhetoric in the current learning plans of the daycare centers is far from the Marxist' approach of the dialectical, structuralized pedagogy. Although Gardner's concept entails the interpersonal intelligence, there is no reference to educating the child as a critical, class conscious and solidary citizen. Thus, while the dialectical, structuralized pedagogy can claim to be a source of inspiration to the form of the learning plans, the content of the present-day education is more focused on individualization and the improvement of the child's individual competencies. As such, the learning plans are targeting the individual child (through the child's parents) and are aiming at the child's development as an individual with certain (Gardner-defined) 
competencies. As it will be explained further in the following, this is far from the collectivism of Marxist' pedagogy.

\section{Final remarks}

The intention of this paper was to dig a little deeper into the founding assumptions of contemporary Danish education, and to unravel the complexity and intertwined-ness of these concepts.

The genealogical analysis shows how two quite different trajectories in contemporary Danish education are in practice intertwined in the 'Law of learning plans in daycare'. Thus, the kinship between dialectical, structuralized pedagogy and learning plans illuminates how the content is replaced in contemporary learning plans. When learning plans are formulated with reference to Gardner's MI theory without reference to the child's relation to the society, the child is not only subjectified as a learning individual but as a self-focused learning individual. While Marxist' pedagogy seem to be the source of inspiration to the form of the learning plans, the content of the education is transformed from a critical and collectivistic upbringing to individualization and optimization of the child's individual competencies. This is the result of an education working form an ideal of encouraging the multiple intelligences in every single child.

This, off course, has implications to the educational practice related to the child, whose individual intelligence profiles the educator is obliged to optimize. But it also has implications to the relation between the educator and the child's parents. Thus, the law implies that the parents can demand of the educator that he continuously takes special care of the development of precisely their child (Hermann, 2003). Furthermore, this understanding implies that schooling commences long before the children actually start at school.

These are some of the effect of the present-day's never-ending encouragement of the child's development. The considerations of the educators contribute to the child's 
self-reflection. As such, they must inevitably imply a categorization of children into those who are 'word-skilled' and those who are 'number-skilled' or 'bodily-skilled' - and those, who are not. This initiates a process of selection of the children in relation to which of the 'intelligences' that are in fact considered as the most valuable in our society. Likewise, the children are subjectified as not only continually learning, but as constantly self-reflective and self-categorizing.

The example also shows how psychological theories, currently Gardner's MItheory and Vygotsky's theory of development conditioned by the more competent other, is employed to legitimize the education. While the theories are determining both how to consider the child and how to optimize his abilities, the cognitive science is actually functioning as a field of power/knowledge related to education. Thus, psychology as a science is an integral part of the norm setting, which determines which personal characteristics and behaviours education must improve or eliminate. As such, psychology is determining the norms for the individual and the boundary between being normal and not normal.

\section{References}

Andersen, Niels Åkerstøm (1999). Diskursive analysestrategier. København: Nyt fra Samfundsvidenskaberne.

Armstrong, Thomas (1994). Multipel Intelligences in the Classroom. Alexandria: Association for Supervision and Curriculum Development.

Bjørgen, Ivar A. (1994). Ansvar for egen læring. Oslo: Tapir.

Broström, Stig (1974). Noget om marxistisk pædagogik i teori og praksis. København: Pædagogstuderendes landsråds forlag. 
Broström, Stig (1977). Struktureret pædagogik i børnehaven - mål, metoder, midler. København: Pædagogstuderendes landsråds forlag.

Broström, Stig (1978). Makarenkos kollektivopdragelse - dansk gruppeopdragelse. København: Forlaget Børn og Unge.

Broström, Stig (1982). 'Dialektisk, struktureret pædagogik' In: Svendsen, Poul \& Stig Kjerulf (red.). Pædagogiske teorier. København: Billesøe og Baltzer.

Broström, Stig (2004). 'Pædagogiske læreplaner i børnehaven'. In: Broström, Stig (red.). Pædagogiske læreplaner - at arbejde med didaktik i bornehaven. Århus: Systime Academic.

Bøgebjerg, Bodil (2006). ‘Læringsstile og undervisningsdifferentiering'. In: Kvan nr. 75, 26. årgang, august 2006.

Christensen, Gerd (2008). Individ og disciplinering. Det pædagogiske subjekts historie. [The Individual and the Discipline. The History of the Pedagogical Subject.] Frederiksberg: Forlaget Samfundslitteratur.

Christensen, Gerd (2013). Projekt grupper - en undersøgelse af subjektiveringsmekanismer $i$ gruppe- og projektarbejde på universitetsniveau. Ph.d. dissertation. Aarhus Universitet.

Darling, John \& Nordenbo, Sven Erik (2003). 'Progressivism'. In: The Blackwell Guide to the Philosophy of Education. London: Blackwell Publishing.

Diderichsen, Agnete (1976). 'Kapitalismens børn - om børns liv og personlighed' In: Børnemarked. København: Borgen. 
Dunn, Rita (2003) Artikelsamling om læringsstile. [A Collection of Papers on Learning Styles.] Frederikshavn: Dafolo Forlag.

Dunn, Rita \& Shirley Griggs (eds.) (2003). Synthetis of the Dunn and Dunn Learning-style Model Research. New York: St. Johns University.

Ellegaard, Tomas \& Stanek, Anja Hvidtfelt (eds.) (2004). Læreplaner i børnehaven - baggrund og perspektiver. Frederiksberg: Roskilde Universitetsforlag.

Fendler, Lynn (2001). 'Educating Flexible Souls'. In: Hultquist, Kenneth (edt.). Governing the Child in the New Millenium. London: Routledge.

Fendler, Lynn (2012). 'The Magic of Psychology in Teacher Education' In: Journal of Philosophy of Education. Vol. 46/3.

Foucault, M. (1979). Discipline E Punish. The birth of the Prison. New York: Vintage books, Random House.

Foucault, Michel (1980). Viljan att veta. Sexualitetens historia I. [The history of the sexuality, part 1]. Södertälje: Gidlunds.

Foucault, Michel (1984). 'Nietzsche, Genealogy, History' In: Rabinow, Paul (edt.) The Foucault Reader. London: Penguin Books.

Foucault, M. (1994). 'The subject and power' In: James D. Faubion (eds.) Power. Essential works of Foucault 1954-1984. Vol. 3. London: Penguin Books. 
Gardner, Howard (1993). Multiple intelligences: the theory in practice. New York : Basic Books,

Gardner, Howard (1996). Intelligence: multiple perspectives. Fort Worth: Harcourt Brace College Publishers.

Gardner, Howard (1999). Intelligence Reframed. Multiple intelligences for the 21st century. New York: Basic Books.

Geuss, Raymond (2002). 'Genealogy as Critique' In: European Journal of Philosophy 10: 2. London: Blackwell Publishers. pp. 209-215.

Hermann, Stefan (2003). 'Fra folkeskole til kompetencemiljø - tendenser i vidensamfundets kapitallogik' In: Borch, C. og L.T. Larsen (red.). Perspektiv, magt og styring. Luhmann og Foucault til diskussion. København: Hans Reitzels Forlag.

Juul, Jesper (1999). Dit kompetente barn. København: Schønberg

Larsen, Steen Nepper (2014). 'At ville noget med nogen - kritiske tanker om pædagogisk arbejde i kontrolsamfundet. In: Tangaard, Lene \& Rømer, Thomas et al (edt.). Uren pædagogik 2. Aarhus: Klim

Lindquist, Gunilla (red.) (2004). Vygotsky om læring som udviklingsvilkår. Århus: Klim. Mik-Meyer, Nanna \& Villadsen Kasper (2007) Magtens former. København: Hans Reitzels Forlag.

Nielsen, Anne Maj (2005). 'De mange intelligenser - psykologi eller pædagogik?' In: Mogens Hansen m.fl. Perspektiver på de mange intelligenser. Frederiksberg: Roskilde Universitetsforlag. 
Nietzsche, Friederich (1999). Zur Genealogie der Moral. Berlin: de Gruyter.

Noujain, E.G. (1987). 'History as Genealogy: An Exploration of Foucault's Approach to History'. In: Griffiths, A.P. (edt.). Contemporary French Philosophy. New York: Cambridge University Press.

Nørgaard, Ellen (1977) Lille barn, hvis er du? København: Gyldendals pædagogiske bibliotek.

Plum, Maja (2011) Dokumenteret faglighed: Analyser af hvordan pædagogisk faglighed produceres gennem læreplanernes dokumentationsteknologi. Ph.d dissertation, University of Copenhagen.

Rasmussen, Kjeld og Stig Broström (1982). En nødvendig pædagogik-dialektisk, struktureret pædagogik. Introduktion og videreudvikling. København: Forlaget Børn og Unge.

Ringsmose, Maria og Katja Lund Knudsen (2005) MI-teoriens mange ansigter - En eksplorativ undersøgelse af danske kommuner og folkeskolers brug af Howard Gardners teori om de mange intelligenser. Master's thesis in Education Research. Institute of Media, Cognition and Communication. University of Copenhagen.

Schmidt, Mariane, Elin Aggerboe og Alice Østergaard (2003). Kom godt i gang med læringsstile. Lærernes inspirations- og kopimappe. Frederikshavn: Dafolo Forlag.

Socialministeriet (2004). Lov om social Service. [The ministry of social affairs. The law concerning social services.] 
Socialministeriet (2003). Bekendtgørelse om temaer og mål i pædagogiske læreplaner. [The ministry of social affairs. Departemental order concerning themes and goals in pedagogical learning plans]

Tamboukou, Maria (1999). ‘Writing genealogies: An exploration for Foucault's strategies for doing research.' In: Discourse: studies in the cultural politics of education. Vol. 20, no. 2.

Villadsen, Kaspar (2006). 'Genealogi som metode - fornuftens tilblivelseshistorier'. I: Bjerg, Ole og Villadsen, Kaspar (red.). Sociologiske metoder. Fra teori til analyse i kvantitative og kvalitative studier. Frederiksberg: Forlaget Samfundslitteratur.

Vygotsky, Lev S. (1971). Tænkning og sprog. [Thinking and Language] København: Hans Reitzels Forlag.

Walkerdine, Valerie (1998). 'Developmental psychology and the child-centred pedagogy: the insertion of Piaget into early education'. In: Julian Henriques, Wendy Hollway, Cathy Venn Urwin, Valerie Walkerdine (eds.) Changing the Subject. London: Routledge.

\section{Internet references}

http://create2009.europa.eu/fileadmin/Content/Downloads/PDF/Projects/National projects DK SKUB The school of the future.pdf (27.09.2011).

http://www.emu.dk/modul/de-mange-intelligenser\# (04.09.2015).

http://dalensbh.viborg.dk/FrontEnd.aspx?id=887929) (06.09.2015)

http://kaskelotten.esbjergkommune.dk/paedagogik/laereplan-for-daginstitutioner.aspx (06.09.2015) 
http://mef.ku.dk/ominstituttet/fag/paedagogik/ (06.09.2015)

(http://www.skub.dk/omskub/paedagogisk inspiration.html (24.11.2014)

http://www.solbakkens.dk/laereplanerfor20142015.asp (06.09.2015)

'To which the teacher is obligated according to Danish Law.

ii This is due to the fact that the critical pedagogy of the Frankfurt- and the Hannover School was founded in the softer Freudo-Marxism while dialectical, structured pedagogy was founded in the Communist and Marxist tradition of the former DDR and the Sovjet Union.

iii Broström also published a book on Makarenko's theory of collective rearing (Broström 1978). This theory is, as well as dialectical structuralized pedagogy, founded in the SovjetMarxism.

\section{Abstract for 'Genealogy and educational research'}

The aim of this paper is to dig a little deeper into the founding assumptions of contemporary Danish education, and to unravel the complexity and intertwined-ness of these concepts. The genealogical analysis in the article is identifying two mayor tendencies in contemporary Danish pedagogy: Individualization and structuralizing. The analyses also show how the two trajectories are interacted in the Danish law of learning plans in day care institutions.

\section{Key-words:}

Howard Gardner, Marxist pedagogy, learning plans, Michel Foucault. 


\section{Writer's profile:}

Gerd Christensen is associate professor at the Department of Media, Cognition and Communication, University of Copenhagen. She has published several books and an amount of articles on matters concerning pedagogical psychology and science studies and methodology in psychology and education studies. Mail: gerd@hum.ku.dk 